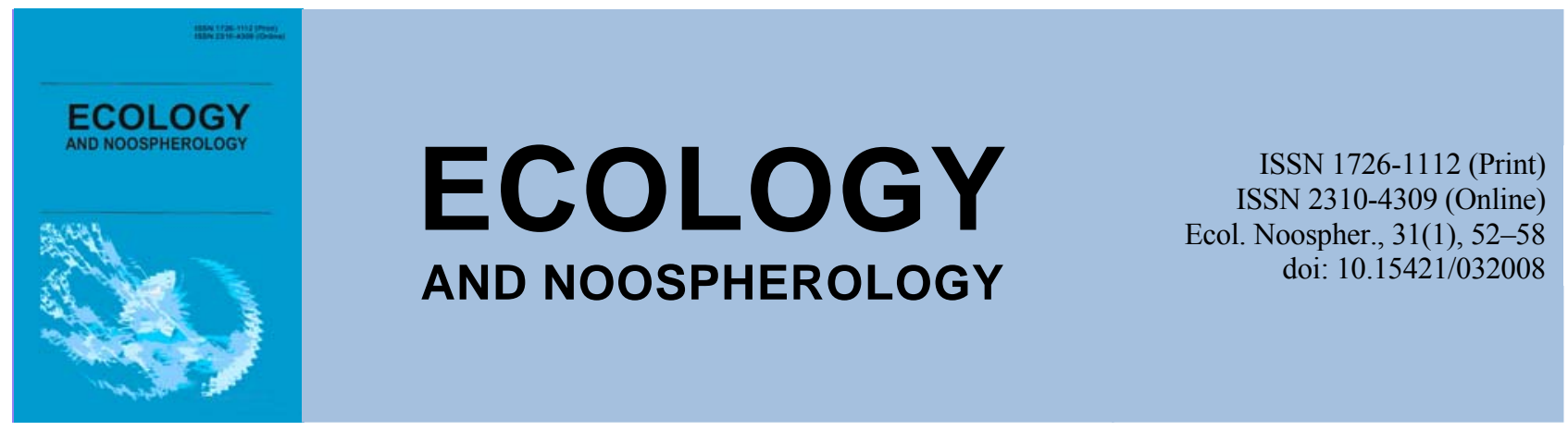

\title{
Comparative analysis of anatomical structure of wood plant leaf under exposure to volatile organic compounds
}

\author{
E. G. Tyulkova
}

Belarusian trade and economic university of consumer cooperatives, Gomel, Belarus

Article info

Received 03.02.2020

Received in revised form 09.02 .2020

Accepted 20.02.2020

Belarusian trade and economic university of consumer cooperatives, pr. October, 50, Gomel, 246029, Belarus. Tel.: +375-29-316-44-83 E-mail: tut-3@mail.ru
Tyulkova, E. G. (2020). Comparative analysis of anatomical structure of wood plant leaf under exposure to volatile organic compounds. Ecology and Noospherology, 31(1), 52-58. doi:10.15421/032008

Industrial enterprises of thermal power engineering, fuel, chemical and petrochemical industry, mechanical engineering, non-ferrous metallurgy are sources of volatile organic compounds, the emissions of which can now reach a significant amount due to changes in technological processes. Studying the effect of volatile organic compounds on changes in anatomical parameters of a plant sheet is a little-studied aspect compared to exposure to oxides of nitrogen, carbon, sulfur, ammonia, heavy metals. The aim of the work was therefore to study the anatomical features of the tree leaf as adaptive features under the influence of emissions from industrial plants containing selected volatile organic compounds. Time preparations of the cross section of the leaf were used for anatomical studies. The thickness of the epidermis, the mesophyll, the number of upper and lower epideric cells, the number of wellheads and their width, the size of the conductive beam, the palisadity coefficient (the ratio of the thickness of the columnar mesophyll to the sum of the thickness of the columnar and spongy mesophyll) and the oral index (the ratio of the number of wellheads to the total number of epidermal cells). Impressions of the upper and lower epidermis were made with colorless varnish. As objects for studying the features of the anatomy of the leaf were chosen the leaves of a number of species of wood plants, which are among the most common near the industrial enterprises of the city of Gomel: drooping birch Betula pendula Roth., maple holly Acer platanoides L. Leaf samples were taken in the zone of influence of emissions of industrial enterprises containing xylenes and butylacetate (JSC «Gomel plant leaves and normals»), as well as benz(a)pyrene (heat and power plant). As a result of the studies, the cells of the columnar mesophyll in the birch leaves were found to have the greatest sensitivity to organic toxicants (xylenes and butylacetate) at the end of the vegetation compared to the maple holly leaves and the parameters of the spongy mesophyll. Drooping birch was characterized as the species in which sclerenchyma in the region of the conducting bundle under technogenic conditions was the thinnest, especially at the beginning of the growing period. Also in birch, when growing around industrial plants, there was a decrease in the number of cells of the upper and lower epidermis compared to control in most variants, especially the upper epidermis in samples exposed to xylenes and butylacetate at the beginning of the growing period. Maple holly showed a more intense decrease in the number of oysters and the value of the oral index compared to control than birch. When exposed to the benz(a)pyrene of heat and power plant emissions, both wood plant species studied showed an increase in mesophyll palisadity coefficient during the most intensive sheet plate formation processes. The conducting bundles of the studied wood plants were characterized by a decrease in the largest diameter when growing under technogenic conditions, most intensively in may at the maple holly. In general, the study of anatomical features of leaf plates of wood plants when growing in the area of exposure to volatile organic compounds of industrial emissions is great interest in terms of understanding the adaptive mechanisms of plants to stress conditions. The seasonal dynamics of changes in anatomical parameters in the birch leaf was characterized by a decrease in their values in most cases in september compared to may in the territory of the industrial enterprises under consideration. In maple holly approximately in equal amounts there was both a decrease and an increase in anatomical parameters between may and september.

Keywords: drooping birch Betula pendula Roth.; maple holly Acer platanoides L.; adaptive changes; anatomy of the leaf 


\title{
Порівняльний аналіз особливостей анатомічної структури листка деревних рослин в умовах впливу летких органічних сполук
}

\author{
О. Г. Тюлькова
}

Білоруський торговельно-економічний університет споживчої кооперащії, м. Гомель, Білорусь

У статті представлені результати вивчення анатомічних особливостей листка одних 3 найбільш поширених представників деревних рослин міського середовища - берези повислої Betula pendula Roth. і клена гостролистого Acer platanoides L., які зростають на території впливу викидів промислових підприємств, що містять у своєму складі летючі органічні з'єднання - ксилоли, бутилацетат, а також бенз(а)пірен. Установлено, що клітини стовпчастого мезофілу в листках берези повислої при завершенні вегетації мали найбільшу чутливість до впливу органічних токсикантів (ксилолів $\mathrm{i}$ бутилацетату) в порівнянні з листками клена гостролистого та параметрами губчастого мезофілу. Береза повисла характеризувалася як вид, у якого склеренхіма в області провідного пучка в техногенних умовах була найбільш тонкою, особливо на початку вегетаційного періоду. Також у берези повислої при зростанні в оточенні промислових підприємств відзначалося зниження кількості клітин верхнього і нижнього епідермісу порівняно з контролем в більшості варіантів, особливо верхнього епідермісу у пробах, схильних до впливу ксилолів і бутилацетату на початку строку вегетації. У клена гостролистого спостерігалося більш інтенсивне зниження кількості продихів і величини продихового індексу порівняно 3 контролем, ніж у берези повислої. При впливі бенз(а)пірену викидів теплоелектроцентралі в обох досліджуваних видів деревних рослин спостерігалося зростання коефіцієнта палісадності мезофілу в період найбільш інтенсивних процесів формування листової пластинки. Провідні пучки досліджуваних деревних рослин характеризувалися зниженням найбільшого діаметра при зростанні в техногенних умовах, найбільш інтенсивно у травні у клена гостролистого.

Ключові слова: береза повисла Betula pendula Roth.; клен гостролистий Acer platanoides L.; адаптивні зміни; анатомія листка

\section{Введение}

Современное промышленное производство резко расширяет спектр источников воздействия и объемы последствий влияния на окружающую среду. Промышленные предприятия теплоэнергетики, топливной, химической и нефтехимической промышленности, машиностроения, цветной металлургии являются источниками летучих органических соединений, выбросы которых в настоящее время могут достигать значительного количества при изменениях в технологических процессах. В результате этого в окружающую среду поступают алканы, циклоалканы, непредельные и ароматические углеводороды, спирты, сложные эфиры. Влияние летучих органических соединений на изменение анатомических параметров листа растений является малоизученным аспектом по сравнению с воздействием оксидов азота, углерода, серы, аммиака, тяжелых металлов (Sergeichik, 1980, 1988; Chernishenko, 2001; Neverova, 2002; Vasfilov, 2003; Govorova, 2004; Maidebura, 2006; Wang-Dong Ji, 2007; Kosobruchov, 2008; Lukina, 2011; Amineva, 2016; Belaeva, 2018; Legoschina, 2018). Поэтому целью работы явилось изучение анатомических особенностей листа древесных растений как адаптивных признаков в условиях воздействия выбросов промышленных предприятий, содержащих в своем составе отдельные летучие органические соединения.

\section{Объекты и методы исследований}

В качестве объектов для изучения особенностей анатомии листа были выбраны листья ряда видов древесных растений, которые являются одними из наиболее распространенных вблизи промышленных предприятий города Гомеля - березы повислой Betula pendula Roth. и клена остролистного Acer platanoides L.

Пробы листьев отбирали в окружении ОАО «Гомельский завод литья и нормалей», который осуществляет производство сельскохозяйственных машин, машиностроительного крепежа, литейной оснастки, нестандартного оборудования, отливки из чугуна, стали и цветных сплавов. В выбросах загрязняющих веществ предприятия значительная доля приходится на неметановые летучие органические соединения, среди которых преобладают ксилолы и бутилацетат. Гомельская
ТЭЦ-2 обеспечивает энергией хозяйственный комплекс Гомельской области, а промышленные предприятия, селитебную и рекреационную зону города теплом. Предприятие является крупнейшим источником поступления в атмосферный воздух углеводородов, оксидов азота, бенз(а)пирена.

Контрольными условиями явилась часть территории национального парка «Припятский» (Хобненское лесничество), максимально приближенная к городу Гомелю и свободная от влияния промышленной деятельности и интенсивного транспорта.

Отбор листьев проводили в течение вегетационного периода (май, сентябрь 2019 г.) с отдельно стоящих деревьев (не менее 3-5 в каждой точке), находящихся в примерно сходных климатических условиях произрастания, с высоты 1,5 м.

Для анатомических исследований использовали временные препараты поперечного среза листа. Измеряли толщину эпидермиса, мезофилла, количество верхних и нижних эпидермальных клеток, количество устьиц и их ширину, размер проводящего пучка, коэффициент палисадности (отношение толщины столбчатого мезофилла к сумме толщины столбчатого и губчатого мезофилла) и устьичный индекс (отношение количества устьиц к общему количеству эпидермальных клеток). Для каждого вида исследуемого древесного растения делали не менее 10 определений анатомо-морфологических параметров с каждой площадки, затем рассчитывали среднее значение. Поперечные срезы делали на серединных участках листа. Слепки верхнего и нижнего эпидермиса делали с помощью бесцветного лака. Цифровые данные анатомических параметров пересчитывались в микрометры (мкм). Математическую обработку цифрового материала выполняли в Excel.

\section{Результаты и их обсуждение}

В результате сравнения анатомических параметров листа исследуемых древесных растений было установлено, что толщина столбчатого мезофилла превышала аналогичный показатель представителей из контрольных условий при $p \leq 0,05$ только в начале периода вегетации в 2019 г. у березы повислой Betula pendula Roth. вблизи ТЭЦ-2 при равном количестве слоев клеток (табл. 1). Можно предположить, что более сильное развитие 


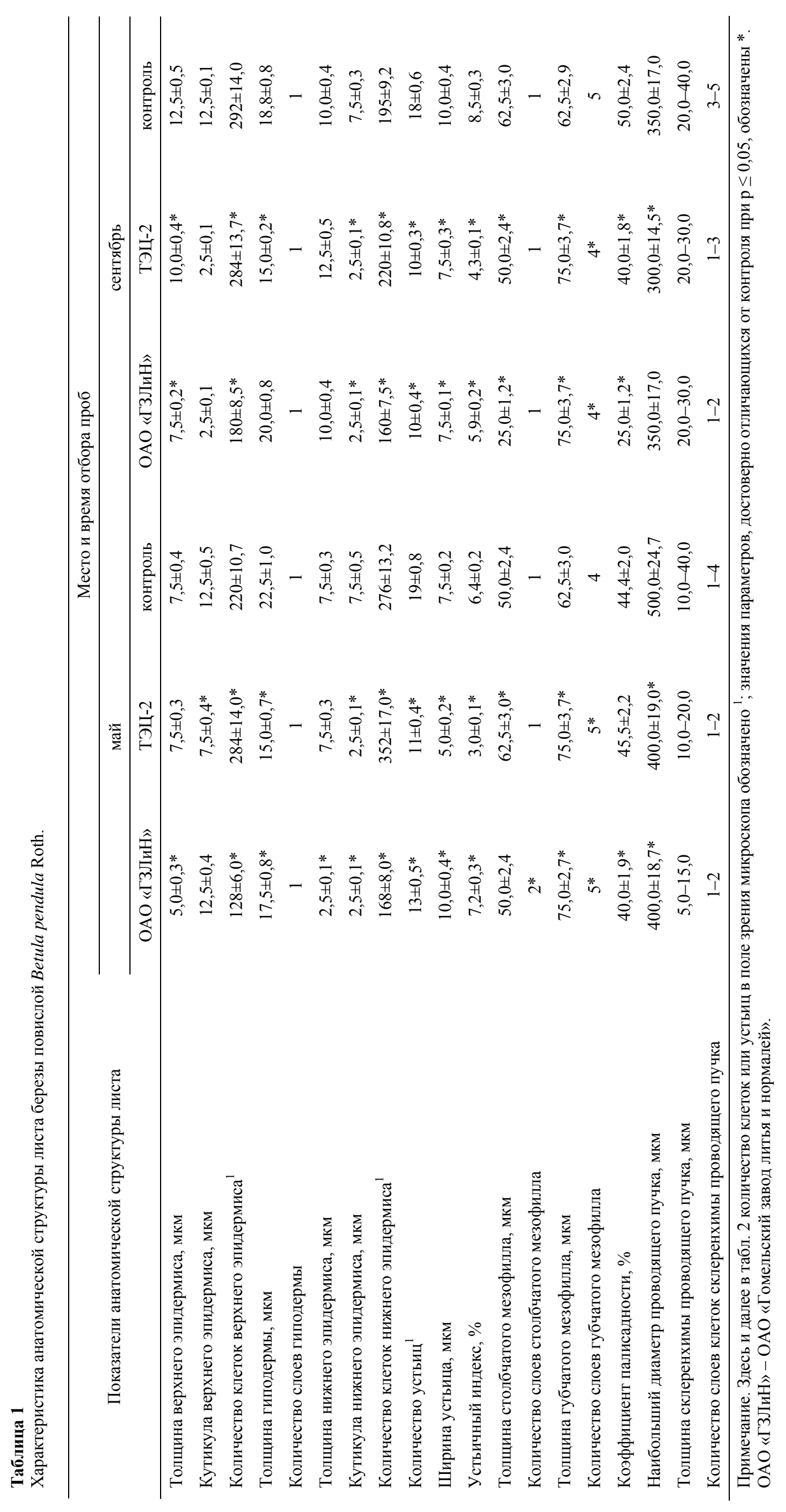


столбчатого мезофилла, которое обеспечивается увеличением высоты клеток и соответственно его толщины у листа березы повислой, характеризует направленность адаптивных процессов при произрастании в условиях влияния бенз(а)пирена, содержащегося в выбросах ТЭЦ-2. Это позволяет растению противостоять действию неблагоприятных условий и обеспечивает более интенсивное протекание процессов фотосинтеза. В остальных вариантах толщина столбчатого мезофилла листа березы повислой была такой же, как в контроле (май, ОАО «ГЗЛиН») или меньше контрольных значений (сентябрь, ОАО «ГЗЛиН», ТЭЦ-2). Уменьшение толщины столбчатого мезофилла по сравнению с контролем при одинаковом количестве слоев клеток может свидетельствовать о повышенной чувствительности этого параметра листа березы повислой к действию ксилолов, бутилацетата и бенз(а)пирена, содержащихся в выбросах предприятий, особенно при завершении периода вегетации.

Клен остролистный Acer platanoides L. в большинстве вариантов, за исключением проб вблизи ТЭЦ-2 в мае, демонстрировал снижение размеров столбчатого мезофилла под влиянием выбросов промышленных предприятий по сравнению с контрольной территорией (табл. 2), что также, как в случае березы повислой, свидетельствует о повышенной чувствительности этого параметра листа к действию ксилолов, бутилацетата и бенз(а)пирена, содержащихся в выбросах предприятий, особенно в конце вегетационного периода.

Изменение размеров губчатого мезофилла у исследуемых видов древесных растений происходило поразному: у березы повислой независимо от периода вегетации толщина губчатого мезофилла в листьях проб, отобранных вблизи промышленных предприятий, превышала контроль, а у клена остролистного, наоборот, в контроле была выше, за исключением представителей, наблюдаемых в окружении ОАО «ГЗЛиН» в начале периода вегетации.

В целом клетки столбчатого мезофилла в листьях березы повислой, отобранных вблизи ОАО «ГЗЛиН» при завершении вегетации, характеризовались наибольшей чувствительностью к воздействию органических токсикантов (ксилолов и бутилацетата) по сравнению с листьями клена остролистного и параметрами губчатого мезофилла (снижение толщины столбчатого мезофилла в этом случае по сравнению с контролем произошло в 2,5 раза).

Следует отметить, что исследуемые представители характеризовались дорсовентральным типом мезофилла с плотно расположенными вытянутыми клетками столбчатого мезофилла и рыхло расположенными клетками губчатого мезофилла.

С учетом толщины губчатого мезофилла был рассчитан коэффициент палисадности, который превышал контрольные значения у березы повислой и клена остролистного вблизи ТЭЦ-2 в начале периода вегетации; был ниже, чем на контрольной территории в мае вблизи ОАО «ГЗЛиН» у обоих видов и в сентябре у березы повислой и равен контрольной величине у клена остролистного в сентябре. Рост коэффициента палисадности мезофилла в период наиболее интенсивных процессов формирования листовой пластинки характеризует адаптивные изменения в анатомическом строении листа при неблагоприятных условиях и увеличение доли клеток столбчатого мезофилла в общем объеме мезофильных клеток, что в наших исследованиях наблюдалось при воздействии бенз(а)пирена выбросов ТЭЦ-2 у обоих исследуемых видов древесных растений.

Устьичный аппарат имеет важное значение в обеспечении физиологической эффективности и жизнедеятельности растения, является основным каналом между растением и воздушной внешней средой и регулирует транспирацию воды с одновременным поглощением углекислого газа для фотосинтеза.
Нами получено, что береза повислая и клен остролистный характеризовались снижением количества устьиц аномоцитного типа и их ширины в большинстве случаев при произрастании вблизи промышленных предприятий, что, с одной стороны, указывает на их возможную деградацию под влиянием техногенного воздействия, а с другой - препятствует поступлению токсикантов внутрь листа. При этом общий устьичный индекс и ширина устьиц в большинстве вариантов оказались на техногенных территориях ниже по сравнению c контролем, что характеризует пониженную долю устьичных клеток в общем количестве эпидермальных клеток. Исключением явилась береза повислая в мае вблизи ОАО «ГЗЛиН», где этот показатель был выше в техногенной зоне по сравнению с контролем (табл. 1). Повышение доли устьиц в листе березы повислой в начале периода вегетации может служить способом улучшения регулирования интенсивности газообмена под влиянием ксилолов и бутилацетата, содержащихся в выбросах ОАО «ГЗЛиН». В целом у клена остролистного по сравнению с контролем наблюдалось более интенсивное снижение количества устьиц и величины устьичного индекса, чем у березы повислой, особенно в мае в пробах листьев, отобранных вблизи ОАО «ГЗЛиН» (в 2,24 раза и в 2,20 раза соответственно).

Проводящие пучки исследуемых древесных растений характеризовались снижением наибольшего диаметра при произрастании в техногенных условиях наиболее интенсивно в мае у клена остролистного (в 1,33 раза вблизи ТЭЦ-2); толщина склеренхимной обкладки и количество слоев клеток склеренхимы также уменьшались по сравнению с контролем в большинстве вариантов, особенно в начале вегетационного периода. Береза повислая явилась наиболее чувствительным по этому параметру видом, у которого склеренхима в области проводящего пучка в техногенных условиях была наиболее тонкой. Снижение толщины склеренхимной обкладки проводящих пучков при произрастании в техногенных условиях является негативным для растений моментом, так как склеренхимные клетки обеспечивают механическую защиту сосудов от давления других тканей.

Немалый экологический интерес представляют особенности анатомического строения эпидермиса листовой пластинки и его толщина, что дополнительно характеризует адаптацию древесных растений к условиям произрастания. Полученные результаты свидетельствуют о том, что у березы повислой при произрастании в окружении промышленных предприятий отмечалось снижение количества клеток верхнего и нижнего эпидермиса по сравнению с контролем в большинстве вариантов, особенно верхнего эпидермиса в пробах вблизи ОАО «ГЗЛиН» в начале периода вегетации (в 1,72 раза). Для клена остролистного была характерна противоположная тенденция, так как у этого представителя верхний и нижний эпидермис в пробах в зоне техногенного влияния в преобладающем количестве случаев отличался повышенным количеством клеток, наиболее интенсивным на территории ТЭЦ-2 в мае (в 2,33 раза). Возможно, это связано со стимулирующим воздействием на рост и развитие растительных клеток выбросов предприятия, содержащих бенз(а)пирен. Из данных литературы известно, что при исследовании реакций растений на воздействие полициклических ароматических углеводородов выявлены дозы бенз(а)пирена, оказывающие симулирующее влияние на рост и продуктивность растений (Belich, 2015).

Верхний эпидермис листьев в преобладающем количестве вариантов оказался более тонким в техногенных условиях по сравнению с контролем, особенно у клена остролистного в мае вблизи ОАО «ГЗЛиН» (в 5 раз). В листьях березы повислой в районе ТЭЦ-2 в сентябре нижний эпидермис был более толстым 


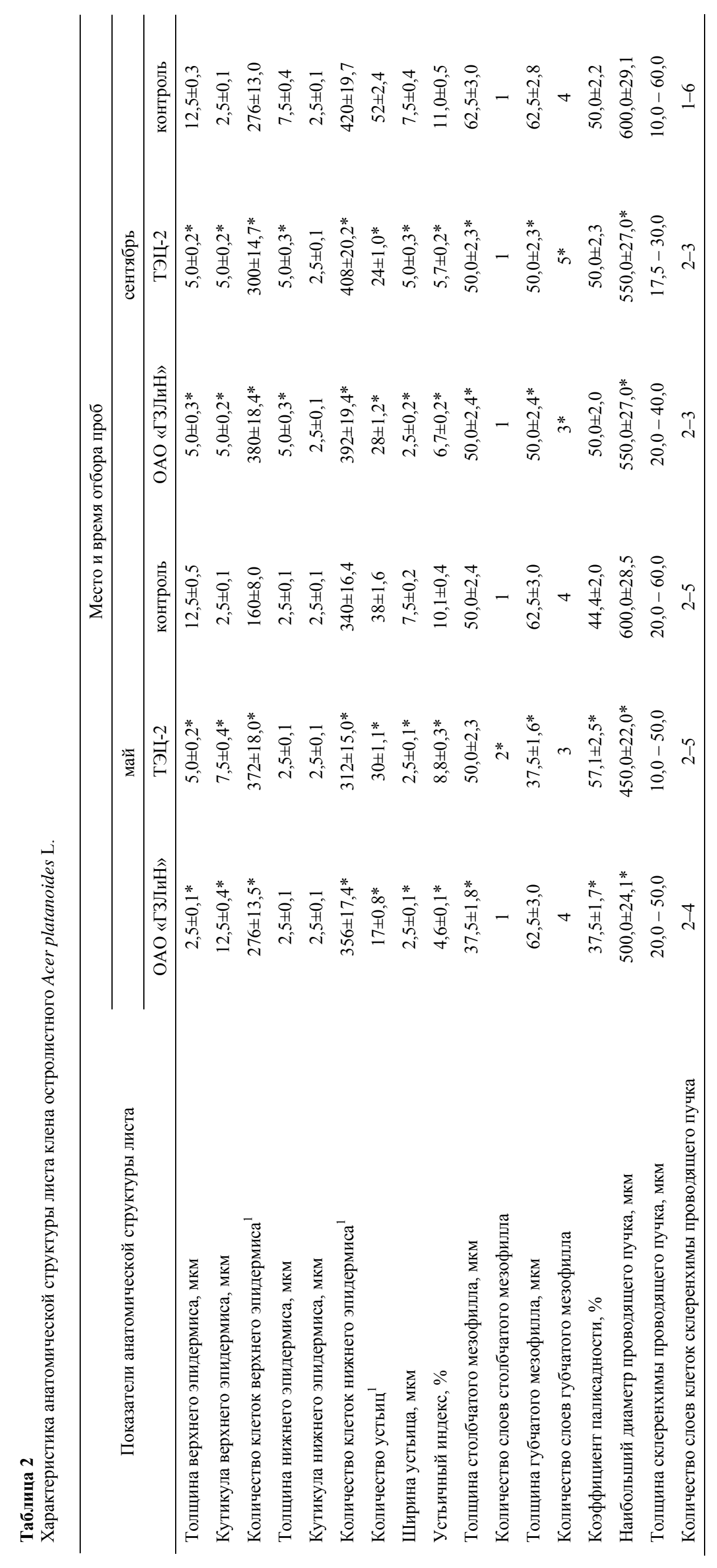


по сравнению с контролем (в 1,25 раза), что, возможно, связано с более интенсивной деятельностью губчатого мезофилла, которая требует повышенного притока воды и минеральных веществ, а также развитием мощных покровных тканей листа в неблагоприятных условиях. Увеличение запасов воды с растворенными в ней минеральными веществами достигается путем накопления не только в межклеточном пространстве губчатого мезофилла, но и в нижнем эпидермисе листа. В остальных случаях нижний эпидермис был более тонким, чем в контроле, особенно у березы повислой вблизи ОАО «ГЗЛиН» в мае (в 3 раза), или равным контрольной величине. Верхний эпидермис березы повислой был более тонким, чем нижний, особенно в конце периода вегетации; у клена остролистного - имел одинаковую величину в большинстве случаев.

Независимо от условий произрастания верхний эпидермис березы повислой был представлен многоугольными неизвилистыми клетками, тогда как клен остролистный отличался наличием амебовидных извилистых клеток верхнего эпидермиса. Клетки нижнего эпидермиса изучаемых древесных растений характеризовались извилистой формой.

В результате сравнения всех исследуемых показателей анатомической структуры листа древесных растений с контрольными значениями выявлено, что наиболее значительное снижение по сравнению с контролем было характерно для кутикулы верхнего эпидермиса листьев березы повислой (сентябрь), кутикулы нижнего эпидермиса, а также толщины нижнего эпидермиса (май, ОАО «ГЗЛиН»); у клена остролистного - для ширины устьиц (май, ОАО «ГЗЛиН», ТЭЦ-2) и толщины верхнего эпидермиса (май, ОАО «ГЗЛиН»).

Превышение контрольных значений параметров анатомической структуры листа также наблюдалось, особенно для величины ширины устьиц и количества слоев столбчатого мезофилла, в листьях березы повислой, отобранных в мае вблизи ОАО «ГЗЛиН»; у клена остролистного - для количества слоев столбчатого мезофилла и коэффициента палисадности (май, ТЭЦ-2).

Сезонная динамика изменений анатомических параметров в листе березы повислой характеризовалась снижением их значений в большинстве случаев в сентябре по сравнению с маем на территории рассматриваемых промышленных предприятий, что особенно было характерно для кутикулы верхнего эпидермиса (ОАО «ГЗЛиН», ТЭЦ-2), толщины и количества слоев столбчатого мезофилла (ОАО «ГЗЛиН»), У клена остролистного приблизительно в равных количествах наблюдалось как снижение, так и увеличение анатомических параметров в период с мая по сентябрь, при этом наиболее интенсивное снижение было характерно для кутикулы верхнего эпидермиса (ОАО «ГЗЛиН», ТЭЦ-2), количества слоев столбчатого мезофилла и устьичного индекса (ТЭЦ-2), а увеличение - для толщины верхнего эпидермиса (ОАО «ГЗЛиН», ТЭЦ-2), нижнего эпидермиса (ОАО «ГЗЛиН»), ширины устьица (ТЭЦ-2).

\section{Выводы}

Изучение анатомических особенностей листовых пластинок древесных растений при произрастании в зоне воздействия летучих органических соединений выбросов промышленных предприятий представляет большой интерес с точки зрения понимания адаптивных механизмов растений к стрессовым условиям. Это выражается в изменении толщины столбчатого и губчатого мезофилла, эпидермиса, количества устьиц, параметров проводящих пучков. В наших исследованиях получено, что клетки столбчатого мезофилла в листьях березы повислой, отобранных вблизи ОАО «ГЗЛиН» при завершении вегетации, характеризовались наибольшей чувствительностью к воздействию органических токсикантов (ксилолов и бутилацетата) по сравнению с листьями клена остролистного и параметрами губчатого мезофилла. Береза повислая характеризовалась как вид, у которого склеренхима в области проводящего пучка в техногенных условиях была наиболее тонкой, особенно в начале вегетационного периода. Также у березы повислой при произрастании в окружении промышленных предприятий отмечалось снижение количества клеток верхнего и нижнего эпидермиса по сравнению с контролем в большинстве вариантов, особенно верхнего эпидермиса в пробах вблизи ОАО «ГЗЛиН» в начале периода вегетации.

У клена остролистного по сравнению с контролем наблюдалось более интенсивное снижение количества устьиц и величины устьичного индекса, чем у березы повислой, особенно в мае в пробах листьев, отобранных вблизи ОАО «ГЗЛиН».

При воздействии бенз(а)пирена выбросов ТЭЦ-2 у обоих исследуемых видов древесных растений наблюдался рост коэффициента палисадности мезофилла в период наиболее интенсивных процессов формирования листовой пластинки. Проводящие пучки исследуемых древесных растений характеризовались снижением наибольшего диаметра при произрастании в техногенных условиях, наиболее интенсивно в мае у клена остролистного вблизи ТЭЦ-2.

\section{References}

Amineva, K. Z. (2016). Ecologo-biologicheskaya characteristica duba chereshchatogo (Quercus robur L.) v usloviax technogennogo zagraznenia (na primere Ufimskogo promishlennogo sentra [Ecological-biological characteristic of cherry oak (Quercus robur L.) under conditions of technogenic pollution (on the example of the Ufa Industrial Center)]. Ufa (in Russian).

Belaeva, U. A. (2018). Ekologo-biologicheskaya otsenka sostoyania Betula pendula Roth. v gorodskix nasagdeniach (na primere g. Tollyatti) [Ecological-biological assessment of Betula pendula Roth. in urban plantations (in the example of Tolyatti)]. Tollyatti (in Russian).

Belich, L. I. (2015). Ekologo-analiticheskaya otsenka raspredelenia polisiklicheskich aromaticheskich uglevodorodov $\mathrm{v}$ technogennich ecosistemach Ugnogo Pribaikalia [Environmentalanalytical assessment of the distribution of polycyclic aromatic hydrocarbons in natural and technogenic ecosystems of Southern Pripikayalia]. Krasnodar (in Russian).

Chernishenko, O. V. (2001). Poglotitelnaya sposobnost i gazoustoichivost drevesnix rastenii $\mathrm{v}$ usloviax goroda [Absorbency and gas stability of wood plants in urban conditions]. Moskva (in Russian).

Govorova, A. F. (2004). Strukturno-funktsionalnie izmenenia rastitelnosti $\mathrm{v}$ usloviax technogennogo zagraznenia na Kolskom poluostrove (na primere kombinata «Severonikel») [Structural and functional changes of vegetation in conditions of technogenic pollution on the Kola Peninsula]. Moskva (in Russian).

Kosobruchov, A. A. (2008). Adaptatsionnie izmenenia fotosinteza pri povischennoi konsentrasii $\mathrm{CO}_{2}$ [Adaptive changes in photosynthesis at elevated concentration $\left.\mathrm{CO}_{2}\right]$. Moskva (in Russian).

Legoschina, O. M. (2018). Adaptivnie reaksii i fitoindikatsionnaya sposobnost drevesnich rastenii $\mathrm{v}$ usloviach technogennogo zagraznenia [Adaptive responses and phytoindicability of wood plants under technogenic pollution]. Tomsk (in Russian).

Lukina, U. M. (2011). Vlianie technogennogo zagraznenia kombinata «Severonikel» na rost i razvitie drevesnix rastenii (na primere Betula czerepanovii Orlova) [Impact of technogenic pollution from Severonikel Plant on the growth and development of wood plants (example Betula czerepanovii Orlova)]. Petrozavodsk (in Russian).

Maidebura, I. S. (2006). Vlianie zagraznenia vozdushnogo basseina goroda Kaliningrada na anatomo-morfologicheskie i 
bioximicheskie pokazateli drevesnix rastenii [Impact of air basin pollution in Kaliningrad on anatomical-morphological and biochemical indices of wood plants]. Kaliningrad (in Russian).

Neverova, O. A. (2002). Kserofitizatsia listev drevesnix rastenii kak pokazatel zagraznenia atmosfernogo vozducha (na primere g. Kemerovo) [Xerophytization of tree leaves as an indicator of atmospheric air pollution (Kemerovo example)]. Lesnoe khozaistvo, 3, 29-33 (in Russian).

Sergeichik, S. A. (1980). Ustoichivost drevesnih rasteni k serovodorodu, serouglerodu, dvuokisi seri i biologicheskaya otsenka atmosfernogo vozduxa $\mathrm{v}$ usloviax Belorusii [Resistance of wood plants to hydrogen sulfide, carbon dioxide, sulphur dioxide and biological purification of atmospheric air in Belarus]. Dnepropetrovsk (in Russian).

Sergeichik, S. A. (1988). Ustoichivost i poglotitelnaya sposobnost drevesnix rastenii $\mathrm{k}$ gazoobraznim zagraznitelam $\mathrm{v}$ usloviax Belorusii [Resistance and absorbency of wood plants to gaseous atmospheric pollutants in Belarus]. Novosibirsk (in Russian).

Vasfilov, S. P. (2003). Vozmognie puti negativnogo vliania kislich gazov na rastenia [Possible ways of negative effects of acid gases on plants]. Jurnal obschei biologii, 2, 146-159 (in Russian).

Wang-Dong, J. (2007). Physiological and ultrastructural responses of Potamogeton crispus to $\mathrm{Hg}^{+2}$. Acta ecol. sin., 7, $2856-2863$. 